Annals of Tropical Research 32[1]:17-30(2010)

(c) VSU, Leyte, Philippines

\title{
Delayed yellowing of broccoli florets by ethanol: Some physio-biochemical changes during storage
}

\author{
Dewoowoogen P. Baclayon ${ }^{1}$ and Toshiyuki Matsui ${ }^{2}$ \\ ${ }^{1}$ Plant Tissue Culture and Disease Diagnostic Laboratory, \\ Research, Development and Extension Office, Southern Leyte State University-Main \\ Campus, Sogod, Southern Leyte, Philippines; \\ ${ }^{2}$ Department of Applied Biological Sciences, Faculty of Agriculture, \\ Kagawa University, Miki-cho, Kagawa-ken, Japan
}

\begin{abstract}
Harvested broccoli heads rapidly senesces after it is severed from the mother plant due to complex metabolic processes occurring in tissues. Specifically, abrupt increase in ethylene and decline in sucrose were reported. To elucidate further these changes, $25 \%$ ethanol was applied in heads prior to storage. The relationship between postharvest yellowing of florets and ethylene production, 1-aminocyclopropane-1carboxylate oxidase (ACO) activity, sugar contents and respiration rate are determined. Results revealed that the onsets of climacteric rise in ACO activity and ethylene production were a day delayed by ethanol application. These results may suggest that ethanol inhibits ethylene synthesis by slowing down the activity of ACO at earlier storage period only. It is likely that due to volatilization of ethanol, the dilute concentration could be much less effective at overcoming its inhibitory effect on ethylene synthesis during the later stage of storage. Furthermore, the almost constant levels of sucrose from days 1 to 3 in the treated florets could be attributed to less consumption of respiratory substrate as exhibited by lower $\mathrm{CO}_{2}$ production. It is, therefore, likely that the relatively higher level of sucrose in treated florets has influenced the responsiveness of the floral tissue to ethylene. Overall, ethanol application appears to delay the metabolic processes which lead to the climacteric rise in ethylene, thereby delaying the onset of floret yellowing in broccoli. Prior to the appearance of visual sign of quality deterioration, significant changes in ACO activity and sucrose level have occurred. Thus, it is considered that yellowing is a late event in broccoli postharvest senescence preceded by significant physio-biochemical changes.
\end{abstract}

Key words: ACO, ethylene, respiration and sugar

Correspondence: D. P. Baclayon Address: Plant Tissue Culture and Disease Diagnostic Laboratory, Research, Development and Extension Office, Southern Leyte State University-Main Campus, Sogod, Southern Leyte, Philippines. E-mail: dpbaclayon@yahoo.com. Tel/Fax:63-53-382-3264. DOI: 10.32945/atr3212.2010 


\section{INTRODUCTION}

The most prominent feature of broccoli postharvest senescence is yellowing of florets (Lurie, 2006) accompanied by degradation of sugars (Pramanik et al., 2005a; Nishikawa et al., 2005). Degreening is the result of chlorophyll degradation (Wang, 1977) and induced by the increased amount of ethylene (Aharoni et al., 1985; Tian et al., 1994). The plant hormone ethylene is produced in response to stress imposed by either harvest or environmental factors. In broccoli, the reproductive structures within the florets produce high amounts of ethylene (Tian et al., 1994). This plant hormone is biosynthesized from methionine via S-adenosylmethionine (SAM) and ACC in higher plants (Abeles et al., 1992) through reactions catalyzed by 1-aminocyclopropane1-carboxylate (ACC) synthase (EC 4.4.1.14) and ACC oxidase (EC 1.4.3) (Liu et al., 2000). ACC synthase catalyzes the conversion of SAM to ACC while ACC oxidase catalyzes the oxidation of ACC to ethylene.

Application of ethanol has been reported to have postharvest benefits in horticultural commodities. For instance, ethanol vapor treatment significantly reduces the climacteric rise in $\mathrm{CO}_{2}$ and ethylene production, lycopene synthesis and chlorophyll loss in tomato fruit (Salveit and Mencarelli, 1988). In carnation, ethanol in the holding solution inhibited climacteric ethylene synthesis and delayed senescence of flowers (Heins, 1980). When applied in combination with hot water, ethanol controls postharvest decay of peaches and nectarines. Immersion of grape berries in ethanol was also found effective in controlling postharvest diseases like gray mold (Mlikota et al., 2005). Considering the beneficial effects of ethanol in these commodities, its application to floral vegetables like broccoli could have significant roles in prolonging shelf life. However, the mechanisms underlying the postharvest physio-biochemical changes of delayed yellowing in broccoli florets applied with ethanol have not been fully established. Hence, this study was conducted to understand the relationships between ethylene production and ACO activity, and carbohydrate contents and respiration rate on their influence in postharvest yellowing of florets held under room temperature. 


\section{MATERIALS AND METHODS}

\section{Plant material and treatments}

Broccoli cv. Endeavor heads were harvested from Kagawa Agricultural Experiment Station, Miki, Kagawa, Japan. The harvested heads were trimmed and the initial weight, color, ethylene and $\mathrm{CO}_{2}$ production were determined. Prior to storage, the heads were immersed in $25 \%$ ethanol for 1 min. After treatment, the heads were wrapped with perforated plastic bags and kept at $20^{\circ} \mathrm{C}$ for five days. Control heads were kept under the same storage condition minus ethanol. At the end of each storage period, the florets were separated from the heads and kept at $-30^{\circ} \mathrm{C}$ until enzyme and carbohydrate content analyses.

\section{Determination of color/hue angle change}

The color change in three different portions of the florets was determined using a chromameter (Nippon Denshoku, Kogyo Co., Ltd.), equipped with an 8-mm measuring head and a $C$ illuminant. The color change was quantified in " $a$ " and " $b$ " color spaces. Positive and negative values of " $a$ " indicate redpurple and green whereas positive and negative values of " $b$ " indicate yellow and blue, respectively (McGuire, 1992). Hue angle was determined as $h^{\circ}=$ $\tan ^{-1}(b / a)$ when $a>0$ and $b>0$ or $h^{o}=180^{\circ}+\tan ^{-1}(b / a)$ when $a<0$ and $b>0$ (Lancaster et al., 1997).

\section{Determination of $\mathrm{C}_{2} \mathrm{H}_{4}$ and $\mathrm{CO}_{2}$ production rates}

Production of $\mathrm{C}_{2} \mathrm{H}_{4}$ and $\mathrm{CO}_{2}$ was determined after the heads were trimmed prior to storage and daily thereafter. Each intact head was sealed in a glass jar held at 5 or $20^{\circ} \mathrm{C}$ for $1 \mathrm{~h}$. A gas sample of $1 \mathrm{ml}$ for $\mathrm{C}_{2} \mathrm{H}_{4}$ and $10 \mathrm{~mL}$ for $\mathrm{CO}_{2}$ determination was taken from the glass jar and injected into a thermal conductivity detector (TCD) gas chromatograph equipped with a 1-m activated charcoal column at $70^{\circ} \mathrm{C}$ (GC-8 AIT, Shimadzu Co., Ltd.) and flame ionization detector (FID) (GC-14B, Shimadzu Co., Ltd.) gas chromatographs, respectively. Actual tissue temperature, however, was not determined. The result was expressed in $\mathrm{nL} \mathrm{g}^{-1} \mathrm{~h}^{-1}$ for $\mathrm{C}_{2} \mathrm{H}_{4}$ production and $\mathrm{ml} \mathrm{CO}_{2} \mathrm{~kg}^{-1} \mathrm{~h}^{-1}$ for respiration rate. 


\section{Extraction and assay of ACO}

Enzyme extraction and assay procedures were performed following the method of Fernandez-Maculet and Yang (1992). Briefly, $2 \mathrm{~g}$ of sample tissue was homogenized in a cooled mortar and pestle with $0.1 \mathrm{~g}$ polyvinylpyrrolidone (PVPP), $0.2 \mathrm{~g}$ sea sand and $4 \mathrm{~mL}$ of extraction buffer containing $0.1 \mathrm{M}$ Tris$\mathrm{HCl}(\mathrm{pH}$ 7.2), $5 \mathrm{mM}$ dithiothreitol DTT, $30 \mathrm{mM} \mathrm{Na}$-ascorbate and $10 \%$ glycerol $(\mathrm{v} / \mathrm{v})$. The homogenate was filtered through four layers of Kimwipes (S-200; Kimberly-Clark Corp.) and the filtrate was centrifuged at 15,000 x g for $30 \mathrm{~min}$ at $4^{\circ} \mathrm{C}$. The supernatant was used as the crude enzyme for the assay of ACC oxidase.

Enzyme assay was carried out in a total volume of $2 \mathrm{~mL}$ consisting of 1.7 $\mathrm{mL}$ extraction buffer, $1 \mathrm{mM} \mathrm{ACC}$ acid, $50 \mu \mathrm{M} \mathrm{FeSO} 4.7 \mathrm{H}_{2} \mathrm{O}$ and $0.2 \mathrm{~mL}$ enzyme extract. The mixture was incubated in a water bath at $30^{\circ} \mathrm{C}$ for $1 \mathrm{~h}$. One milliliter of gas sample produced in $13.2 \mathrm{~mL}$ test tube sealed with silicon rubber cap was taken using a plastic hypodermic syringe and injected into the GC with flame ionization detector (GC-14B, Shimadzu Co., Ltd., Japan). Ethylene concentration was expressed as nanoliter per gram per hour.

\section{Determination of carbohydrate contents}

Total sugar was extracted by homogenizing approximately four-gram of sample tissue with $0.5 \mathrm{~g}$ sea sand and $10 \mathrm{~mL}$ of distilled water in a cooled mortar and pestle. The extract was centrifuged at $11,000 \mathrm{xg}$ for $10 \mathrm{~min}$ and the supernatant was filtered through a cellulose nitrate membrane filter $(0.5$ um pore size; Toyo, Japan). Soluble sugars were analyzed by high performance liquid chromatography (HPLC) with a silica gel-packed (C 610) stainless steel column $(10.7 \mathrm{~mm} \mathrm{ID} \mathrm{x} 30 \mathrm{~cm}$ ) and D-2500 chromato-Integrator (Hitachi, Japan). The filtered air-free water was pumped through the column at a flow rate of $1 \mathrm{~mL} \mathrm{~min}^{-1}$. The pressure was adjusted to $24-15 \mathrm{~kg} \mathrm{~cm}^{-2}$ and the column temperature was maintained at $60^{\circ} \mathrm{C}$. Sucrose, glucose and fructose were identified by their retention times and quantitatively determined. 
Analysis of data

A randomized complete block design was adopted with three replications. The level of significance was calculated from the F value of ANOVA. Mean comparison was achieved by Duncan's multiple range test.

\section{RESULT}

\section{Color/hue angle change}

The hue angle values of heads were maintained for 3 days from treatment (Fig. 1A). Thereafter, the hue angle value of the control heads abruptly declined until the end of the storage period. Trace of yellow in the florets appeared on day 3 and progressed to severe yellowing at day 5 (Fig. 1B). In the ethanoltreated heads, there was only a slight decline in hue angle. The greenness of the treated head at day 5 was comparable with that of the control florets at day 4.

$\mathrm{C}_{2} \mathrm{H}_{4}$ production of intact head. A climacteric rise in ethylene production was observed immediately after harvest in the control heads while that of the treated heads was delayed by one day (Fig. 2A). Lower ethylene production was found in the treated heads until day 2 but after reaching a peak on day 3 , the treated heads produced a significantly higher ethylene than the control heads.

\section{Activity of $A C O$}

ACO activity in the control florets slightly increased after treatment while that of the treated heads was maintained to a constant level until day 1 (Fig. 2B). Thereafter, a rapid increase in enzyme activity was found in tissues of both treatments. Control tissues showed higher ACO activity but peaked a day earlier than the treated florets. 


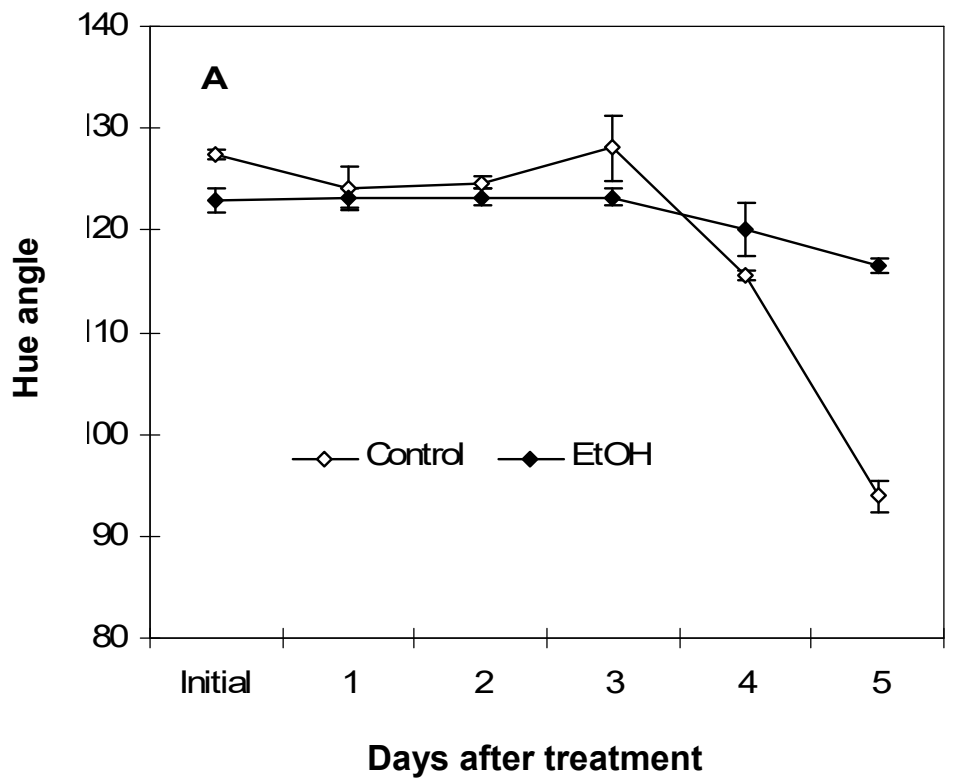

Figure 1a. Changes in hue angle value (A) and progress of yellowing (B) in broccoli florets treated with ethanol prior to storage at room temperature 


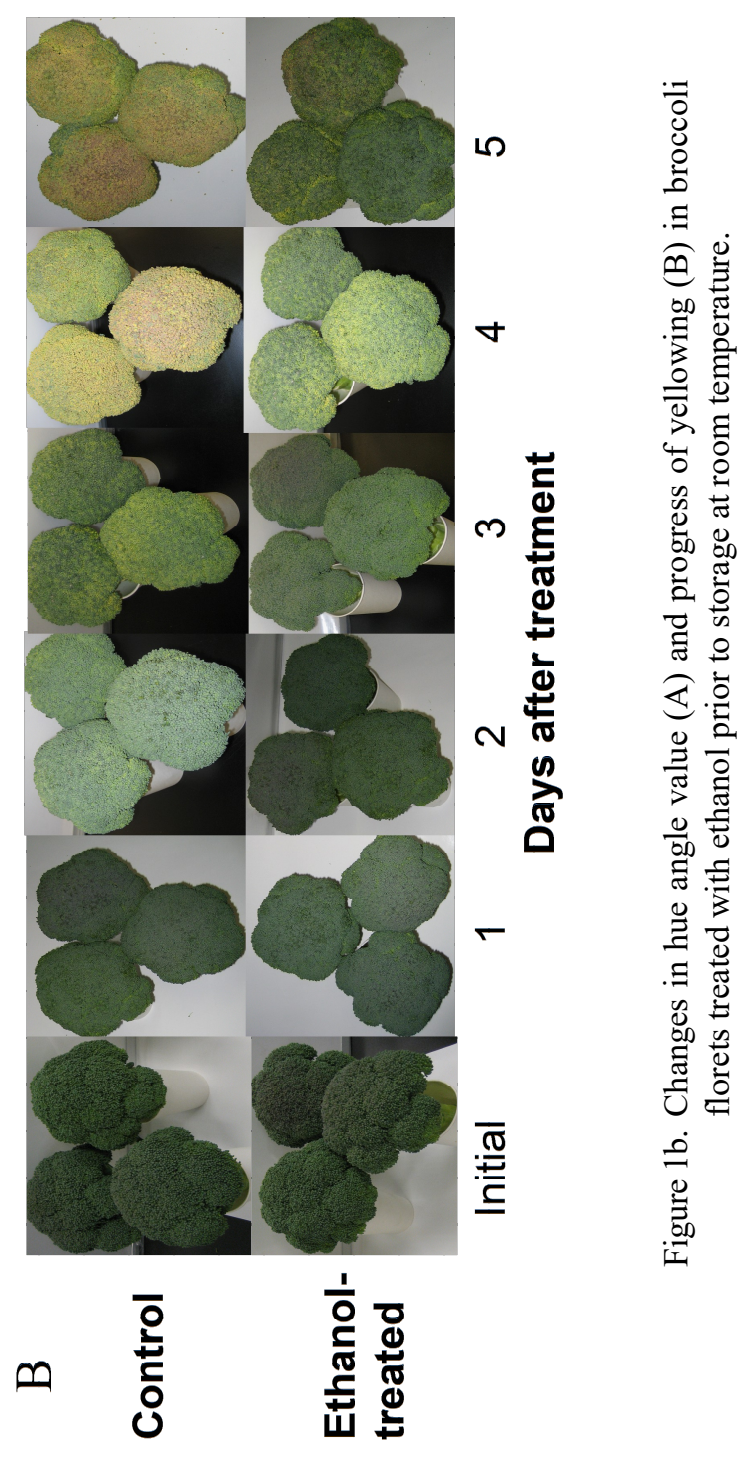



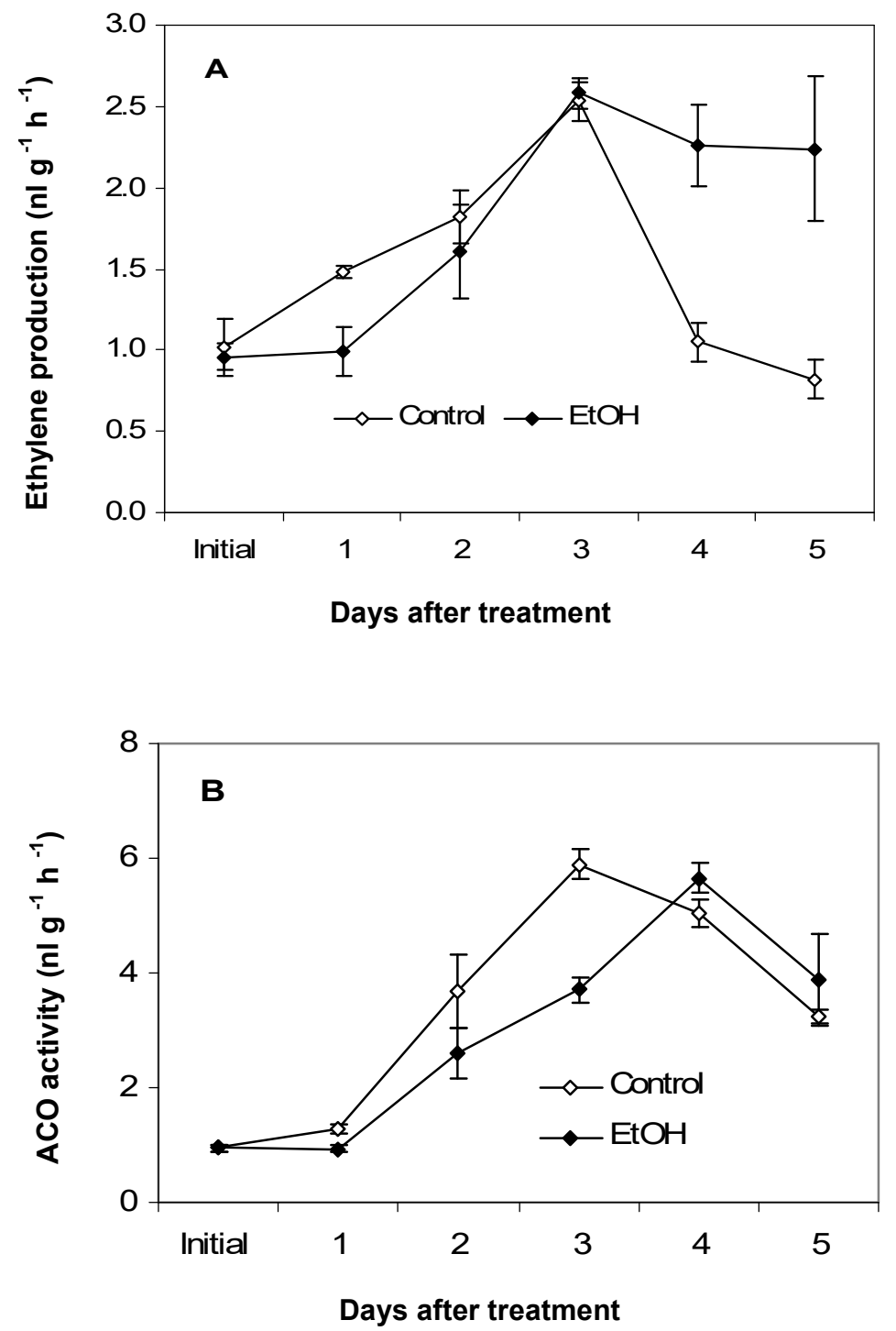

Figure 2 Changes in ethylene production (A) of intact broccoli head and ACO activity (B) in the floret portion of the head treated with ethanol prior to at storage room temperature. 


\section{Carbohydrate contents of the floret tissue}

Sucrose content in florets of both treatments rapidly declined a day after harvest (Fig. 3A). While the level in the control tissues continuously dropped, that of the ethanol-treated floret maintained its sucrose level until day 3. Glucose content, on the other hand, declined in both treatments after harvest. However, the level in the control tissue was higher than that of the treated heads until day 3 (Fig. 3B). Among the three sugars, only fructose had improved its level until day 2 in the control heads while a decline was observed in the treated heads (Fig. 3C). The control tissues significantly contained higher level of fructose throughout the storage duration.

\section{Respiration rate of intact head}

High $\mathrm{CO}_{2}$ production in intact heads was observed initially but declined rapidly on day 1 in both treatments (Fig. 4). While $\mathrm{CO}_{2}$ production in the ethanol-treated heads was slightly lower than the control for most of the time, the trend followed roughly the same as the control heads at the beginning until the end of the storage period.

\section{DISCUSSION}

Under normal atmospheric condition, harvested broccoli heads senesces rapidly with florets turning yellow due to chlorophyll breakdown (Hyodo et al., 1995) accompanied by degradation of sugars (Nishikawa et al., 2005; Pramanik et al., 2005a). Delaying postharvest senescence by ethanol has been reported in some horticultural commodities (Salveit and Sharaf, 1992; Heins, 1980). In this study, broccoli florets treated with $25 \%$ ethanol prior to storage delayed yellowing of florets. The florets remained green until day 3 from treatment with only slight decline in greenness compared with that of the control heads in which yellowing progressively developed until day 5 (Figs. $1 \mathrm{~A}$ and $\mathrm{B})$. It has been demonstrated that the reproductive structures within the florets produce high amounts of ethylene and play a role in broccoli senescence (Tian et al., 1997). The result of this experiment showed that climacteric rise in ethylene production proceeded immediately after harvest in 

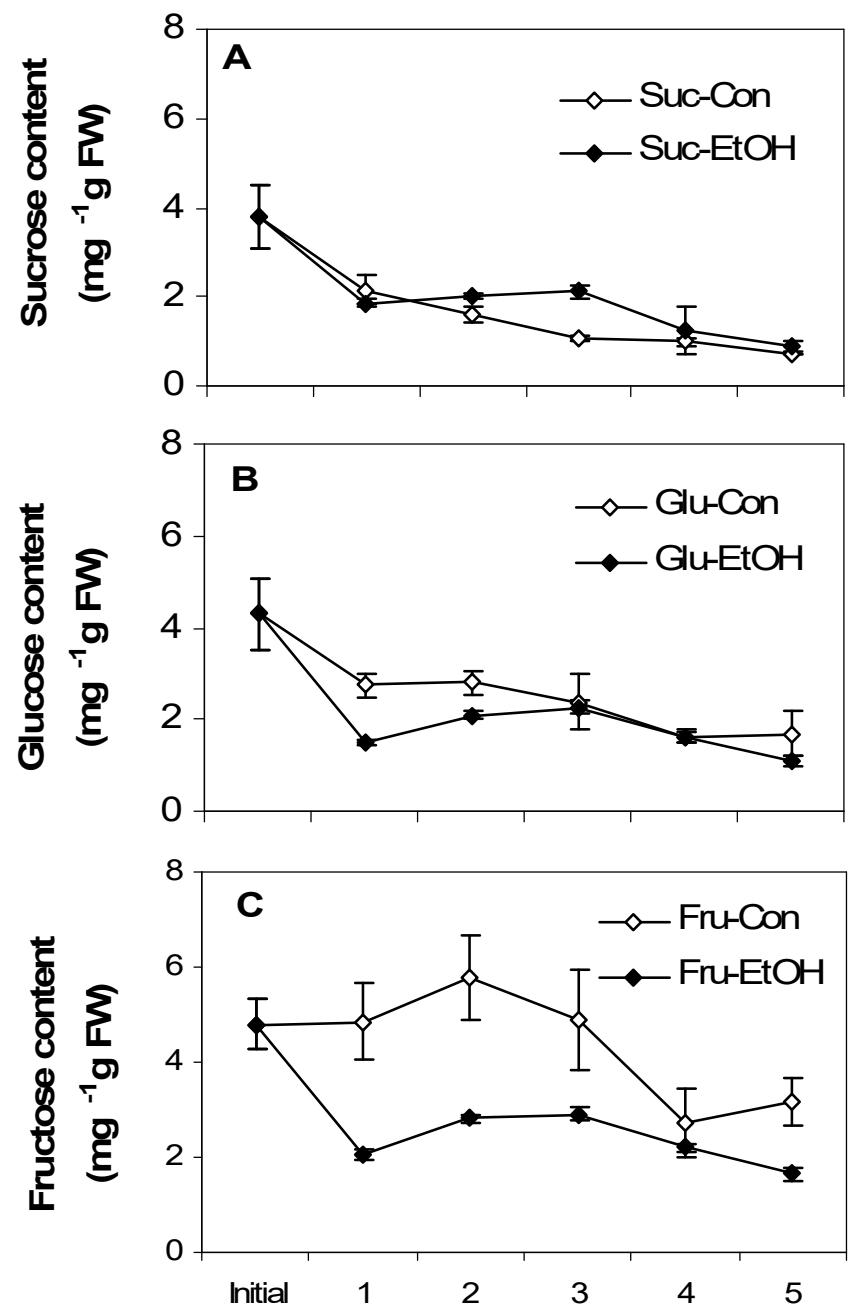

Figure 3 Changes in sucrose (A), glucose (B) and fructose (C) contents in the floret portion of the head treated with ethanol prior to storage room temperature 


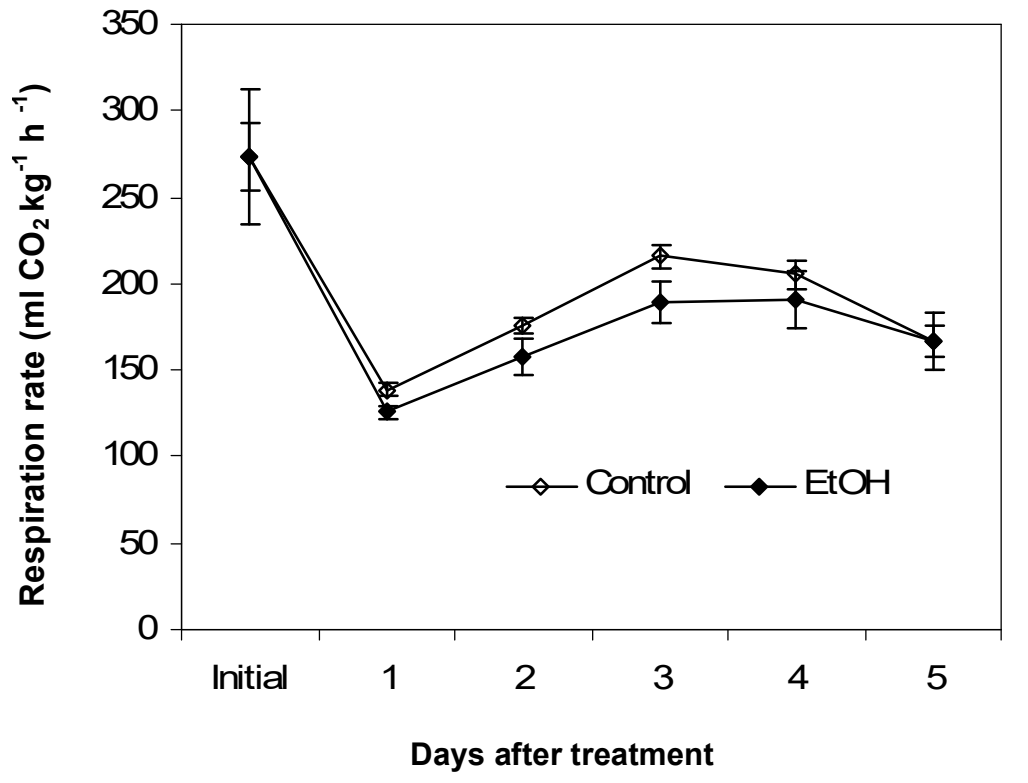

Figure 4 Changes in respiration rate of intact broccoli head treated with ethanol prior to storage at room temperature. 
the control heads at a slower rate within $24 \mathrm{~h}$ while that of the treated heads was delayed by one day and the amount was relatively low before reaching a peak on day 3 (Fig. 2A). It is clear that the early rise in ethylene production has advanced the degreening process of the florets in the control heads. Although ethylene was remarkably higher in the ethanol-treated heads after day 3 , the progress of yellowing was not as fast as that of the control heads. It is likely that ethanol appears to inhibit ethylene action (Salviet and Mencarelli, 1988). The constant ACO activity after harvest in the treated heads until day 1 (Fig. 2B) suggest that ethanol could inhibit ethylene synthesis at earlier stage of storage. Thereafter, due to the volatilization of ethanol, the dilute concentration could be much less effective at overcoming its inhibitory effect on ethylene synthesis at the later stage of storage. Therefore, it is suggested that ethanol could be applied repeatedly throughout the storage durations. This suggestion, however, needs further elucidation.

Accompanying postharvest quality deterioration in harvested vegetables is the rapid decline in sugars (Irving and Hurst, 1993; Suthumchai et al., 2007; Sitthiwong et al., 2007). In broccoli, abrupt decline in sucrose level was observed in both treatments after day 1 of storage (Fig. 3A). However, the level in ethanol-treated florets remained at almost constant level from days 1 to 3 and the amount was consistently higher most of the time than the control. It is likely that due to lower $\mathrm{CO}_{2}$ production in ethanol-treated heads (Fig. 4), consumption of respiratory substrate could be minimal. Furthermore, it is possible that ethanol-treatment slowed down the activity of sucrose degrading enzymes such as acid invertase or sucrose synthase. Although the activities of these enzymes were not measured in this study, the lower levels of sucrose component monosaccharide, glucose and fructose in the ethanol-treated heads throughout the storage duration (Figs. 3B and C) would support this claim. As a result, higher level of sucrose in the ethanol-treated heads could have influence the responsiveness of floret tissues to ethylene. Nishikawa et al. (2005) suggested that sucrose and glucose can affect the rate of ethylene biosynthesis and that high level of sugars decrease ethylene sensitivity in harvested broccoli florets. The mechanism as to how exactly sugar level influence ethylene sensitivitymerits further elucidation.

The results of this study further suggest that ethanol appears to delay some important metabolic processes which lead to the climacteric rise in ethylene, thereby delaying the onset of floret yellowing in broccoli. Prior to the appearance of visual sign of quality deterioration, significant changes in 
ACO activity and sucrose level have occurred. Thus, it is considered that yellowing is a late event in broccoli postharvest senescence preceded by significant physio-biochemical changes.

\section{REFERENCES}

ABELES, F.B., P.W. MORGAN and M.E. SALVEIT, JR. 1992. Ethylene in Plant Biology (2nd ed), Acad. Press, Inc., San Diego, CA, USA.

AHARONI, N., S. PHILOSOPH-HADAS and R. BARKAI-GOLAN. 1985. Modified atmospheres to delay senescence and decay of broccoli. Proc. 4th Natl. Controlled Atmosphere Conf., Dept. of Hort. Sci., Raleigh, N.C. Hort. Rpt. 126: 169-177.

FERNANDEZ-MACULET, J.C. and S.F. YANG. 1992. Extraction and partial characterization of the ethylene-forming enzyme from apple fruit. Plant Physiol. 99: 751-754.

HEINS, R.D. 1980. Inhibition of ethylene synthesis and senescence in carnation by ethanol. J. Amer. Soc. Hort. Sci. 105: 141-144.

HYODO, H., S. MOROZUMI, C. KATO, K. TANAKA and H. TERAI. 1995. Ethylene production and ACC oxidase activity in broccoli flower buds and the effect of endogenous ethylene on their senescence. Acta Hort. 394: 191-198.

IRVING, D.E. and P.L. HURST. 1993. Respiration, soluble carbohydrates and enzymes of carbohydrate metabolism in tips of harvested asparagus spears. Plant Sci. 94: 89-97.

LANCASTER, J.E., C.E. LISTER, P.F. REAY and C.M. TRIGGS. 1997. Influence of pigment composition on skin color in a wide range of fruit and vegetables. J. Amer. Soc. Hort. Sci. 122: 594-598.

LIU, X.J., R. NAKANO, Y. KUBO and A. INABA. 2000. Extraction and properties of 1aminocyclopropane-1-carboxylate synthase in banana fruit. J. Jpn. Soc. Hort. Sci. 69: 696-701.

LURIE, S. 2006. The effect of high temperature treatment on quality of fruits and vegetables. Proc. IVth IC on MQUIC. Acta Hort. 712: 165-173.

MCGUIRE, R.G. 1992. Reporting of objective color measurements. HortScience 27: 1254-1255.

MLIKOTA, G.F., J.L. SMILANICK, J.M. GHOSOPH and D.A. MARGOSAN. 2005. Impact of postharvest hot water or ethanol treatment of table grapes on gray mold incidence, quality and ethanol content. Plant Disease 89: 309-316.

NISHIKAWA, F., T. IWAMA, M. KATO, H. HYODO, Y. IKOMA and M. YANO. 2005. 
Effect of sugars on ethylene synthesis and responsiveness in harvested broccoli florets. Postharvest. Biol. Technol. 36: 157-165.

PRAMANIK, B.K., T. MATSUI, H. SUZUKI and Y. KOSUGI. 2004a. Changes in acid invertase activity and sugar distribution during postharvest senescence in broccoli. Pakistan J. Biol. Sci. 7: 679-684.

SALVEIT, M.E., JR. and A.R. SHARAF. 1992. Ethanol inhibits ripening of tomato fruit harvested at various degrees of ripeness without affecting subsequent quality. J. Amer. Soc. Hort. Sci. 117: 793-798.

SALVEIT, M.E., JR. and F. MENCARELLI. 1988. Inhibition of ethylene synthesis and action in ripening tomato fruit by ethanol vapors. J. Amer. Soc. Hort. Sci. 113: 572-576.

SITTHIWONG, K., T. MATSUI, N. OKUDA and Y. KOSUGI. 2007. Cloning and sequencing of sucrose synthase cDNA from vegetable soybean and its expression during storage at $20^{\circ} \mathrm{C}$. Biotechnology 6: 184-192.

SUTHUMCHAI, W., T. MATSUI, K. KAWADA and Y. KOSUGI. 2007. Sugar metabolizing enzymes activities in lettuce head during low temperature storage. Asian J. Plant Sci. 6: 568-576.

TIAN, M.S., C.G. DOWNS, R.E. LILL and G.A. KING. 1994. A role for ethylene in the yellowing of broccoli. J. Amer. Soc. Hort. Sci. 119: 276-281.

TIAN, M.S., T. ISLAM, D.G. STEVENSON and D.E. IRVING. 1997. Color, ethylene production, respiration and compositional changes in broccoli dipped in hot water. J. Amer. Soc. Hort. Sci. 122: 112-116.

WANG, C.Y. 1977. Effect of aminoethoxy analog of rhizobitoxine and sodium benzoate on senescence of broccoli. HortScience 12: 54-56. 